Selcuk Journal of Agriculture and Food Sciences

http://sjafs.selcuk.edu.tr/sjafs/index

Research Article
SJAFS

(2019) 33 (1), 7-13

e-ISSN: 2458-8377

DOI: $10.15316 /$ SJAFS.2019.149

\title{
Improvement of Physical and Sensory Properties of Bread Containing Cereal-Legume Composite Flour
}

\author{
Elif YAVER ${ }^{1}$, Nermin BILGiçLi ${ }^{1, *}$ \\ ${ }^{1}$ Necmettin Erbakan University, Engineering and Architecture Faculty, Food Engineering Department, Konya, Turkey
}

\section{ARTICLE INFO}

Article history:

Received date: 27.02 .2019

Accepted date: 12.03 .2019

\section{Edited by:}

Cemalettin SARIÇOBAN; Selçuk University, Turkey

\section{Reviewed by:}

Sultan ARSLAN TONTUL; Selcuk

Universiy, Turkey

Ayşe Büşra MADENCİ; Necmettin

Erbakan University, Turkey

\section{Keywords:}

Additives

Bread

Cereal

Flat bread

Legume

\begin{abstract}
In this study, cereal-legume flour blend (CLFB) containing an equal amount of cereal (rye, barley and oat) and legume (chickpea, soy and lupin) were used in the formulations of commercial bread (CB) and traditional flat bread (TFB) at $25 \%$ level. The adverse effect of CLFB on technological quality of breads was tried to eliminate using different combinations of additives (vital gluten, fungal alpha amylase, sodium stearoyl-2-lactylate, ascorbic acid, transglutaminase, glucose oxidase, lipase, pentosanase and xylanase) in both breads. Combinations with vital gluten, sodium stearoyl-2-lactylate, fungal alpha amylase, ascorbic acid and xylanase or pentosanase provided the highest bread specific volume along with CB prepared with $100 \%$ wheat flour. The additive combination including xylanase also revealed the lowest hardness in $\mathrm{CB}$, as well as resulted in a decrease in the spread ratio and hardness values of TFB. Crust colour values $\left(L^{*}, a^{*}\right.$ and $\left.b^{*}\right)$ were significantly $(\mathrm{P}<0.05)$ affected by all of the additive combinations in both $\mathrm{CB}$ and TFB. The combinations containing pentosanase or xylanase displayed a better improvement on the pore structure, appearance and overall acceptability scores of CB and TFB including $25 \%$ CLFB in comparison to other additives.
\end{abstract}

\section{Introduction}

Cereals such as rye, barley and oat are of great sources of carbohydrates, proteins, dietary fibres, phytochemicals, minerals and vitamins (B-complex and E) (Slavin, 2004). Legumes (chickpea, soy, lupin, etc.) have a remarkably high protein content, along with a good amount of lipid, dietary fibres, vitamins and minerals such as $\mathrm{Ca}, \mathrm{Fe}, \mathrm{Zn}, \mathrm{Mg}, \mathrm{P}$ and $\mathrm{K}$ (Garcia et al., 1997). Due to the rich nutritional composition of whole flours of cereals and legumes, they are used as functional ingredients in food formulations such as bread. Most common diseases such as obesity, diabetes, heart diseases and some type of cancer are associated with an unhealthy diet which lacks the beneficial nutrients for consumption. A number of studies have suggested that a high intake of whole flours of cereal and legume in diet might have a positive effect on human health and prevention of the diseases mentioned (Belski, 2012; Malkki and Virtanen, 2001). Although the nutritional and functional properties of breads improve in the presence of whole flours of cereal and legume, the

\footnotetext{
* Corresponding author email: nerminbil2003@ hotmail.com
}

technological properties of the end product are partially lost. Therefore, using some additives (vital gluten, oxidants, emulgators and enzymes) can help enhance the technological quality of the end-product.

Unique visco-elastic properties of vital wheat gluten improve bread volume and dough strength as well as mixing tolerance and handling properties of dough. It increases shelf life of the bread by increasing the water holding capacity of dough and gives softness to bread. Hence, vital gluten allows to enhance the nutritional value of refined wheat bread with various cereal and legume flours and renders it acceptable for consumers (Day et al., 2006).

Sodium stearoyl-2-lactylate (SSL) is an emulgator that is used as an anti-staling and dough improving agent (Stampfli and Nersten, 1995). Van Steertegem et al. (2013) reported that SSL interacts with gluten and strengthen dough structure. Ascorbic acid (AA) is another bread improving agent that also possess an anti-staling effect (Gujral et al., 2003).

Fungal alpha amylase (FAA), transglutaminase (TG), glucose oxidase (GO), lipase, pentosanase and xylanase are enzymes which can be used in bakery industry to enhance bread quality. FAA reduces staling 
rate, increases bread volume and improves handling properties, pore structure, crust and crumb colour (Maeda et al., 2003). TG enzyme changes chemical and functional properties of glutenin fraction and improves dough properties. Numerous studies have been reported that TG is used as a dough strengthener, loaf volume and crumb softness enhancer, handling properties improver (Gerrard et al., 1998; Seravalli et al., 2011). GO is an enzyme that catalyses D-glucose to D-gluconic acid and hydrogen peroxide. The hydrogen peroxide causes the formation of disulfide bonds and increases gelling properties of water-soluble pentosanes (Gujral and Rosell, 2004). Zeng et al. (2011) showed that alpha amylase and GO enzymes improved specific volume and pore structure of bread, with a delay in bread staling. Lipase enzyme provides in the formation of emulgators by hydrolyzing lipids. This enzyme has an anti-staling effect, and it improves rheological properties of dough, as well as increases bread volume (Castello et al., 1998; Olesen et al., 2000). Pentosanase hydrolyses high molecular weight arabinoxylans and affects dough and bread quality, provides a higher specific volume, softer dough structure and more sulphydryl groups (Rouau and Surget, 1998; Steffolani et al., 2010). Xylanase increases moisture content, volume, specific volume and overall acceptability while used in breadmaking (Shah et al., 2006). Hemalatha et al. (2014) reported that xylanase and amylase enzyme combination delays bread staling and alters rheological properties of bread.

The main objective of this study is therefore to evaluate the effects of different additive combinations on the physical and sensory properties of commercial bread (CB) and traditional flat bread (TFB) including $25 \%$ of cereal-legume flour blend (CLFB).

\section{Materials and Methods}

\subsection{Materials}

Wheat flour (commercial wheat flour contains $0.79 \%$ ash and $12.41 \%$ protein), baker's yeast, salt, chickpea and defatted whole soy flour were purchased from a local market in Konya, Turkey. Hull-less barley, hull-less oat and rye were obtained from Sağlık Tarım (Konya, Turkey). Traditionally debittered lupin seeds were provided by Doğanhisar, Konya, Turkey. Cereals and legumes (except soy) were milled $(<500 \mu \mathrm{m})$ on a hammer mill (Perten 3100, Huddinge, Sweden) with $100 \%$ extraction ratio. Vital gluten, FAA, SSL, AA, TG, GO, lipase, pentosanase and xylanase were supplied from Vatan Gida (İstanbul, Turkey).

\subsection{Preparation of CLFB and bread samples}

CLFB was prepared by mixing an equal amount of barley, oat, rye, soy, chickpea and lupin flours. CLFB was replaced with refined white wheat flour of $25 \%$ ratio $(w / w)$ for preparation of bread formulations.

For the preparation of control-1 (C1) CB; $100 \mathrm{~g}$ wheat flour, $3 \mathrm{~g}$ baker's yeast, $1.5 \mathrm{~g}$ salt and water (determined by the farinograph absorption) kneaded in the mixer (Kenwood KMX750RD, Hampshire, UK) until obtaining a homogenous dough. The dough was left in bulk to fermentation $\left(30+30 \mathrm{~min}, 30^{\circ} \mathrm{C}\right)$ and then rest at $30^{\circ} \mathrm{C}$ for $60 \mathrm{~min}$. At the end of this period, dough samples were baked at $240^{\circ} \mathrm{C}$ for $15 \mathrm{~min}$ in an oven (Beko MF6, İstanbul, Turkey). In control-2 (C2) CB sample, wheat flour was replaced with CLFB of $25 \%$ ratio. To produce $\mathrm{CB}$ with $25 \%$ of CLFB and additives (from $\mathrm{C} 3$ to $\mathrm{C} 9$ ); vital gluten $(2.5 \%)$, FAA $(0.003 \%)$, SSL $(0.5 \%)$, AA $(0.01 \%)$, TG $(0.5 \%)$, GO $(0.001 \%)$, lipase $(0.001 \%)$, pentosanase $(0.004 \%)$ and xylanase $(0.004 \%)$ were supplemented into bread formulations. Table 1 shows the enzyme combinations used in this study. The same procedure applied for $\mathrm{C} 1$ was also employed for C2-C9 CB.

Table 1

Combinations of additives used in $\mathrm{CB}^{1}$ and $\mathrm{TFB}^{2}$ formulations.

\begin{tabular}{|c|c|}
\hline Formulations & Combinations of additives \\
\hline C1 (Control-1) & $0 \% \mathrm{CLFB}^{3}$ (without additives) \\
\hline C2 (Control-2) & $25 \%$ CLFB (without additives) \\
\hline $\mathrm{C} 3$ & $25 \%$ CLFB (Gluten+SSL ${ }^{4}+\mathrm{FAA}^{5}$ ) \\
\hline $\mathrm{C} 4$ & $25 \%$ CLFB (Gluten+SSL+FAA+AA $\left.{ }^{6}\right)$ \\
\hline $\mathrm{C} 5$ & $25 \%$ CLFB (Gluten+SSL+FAA+TG ${ }^{7}$ ) \\
\hline C6 & $25 \%$ CLFB (Gluten+SSL+FAA+GO ${ }^{8}$ ) \\
\hline $\mathrm{C} 7$ & $\begin{array}{l}25 \% \text { CLFB } \\
\text { (Gluten+SSL+FAA+Lipase) }\end{array}$ \\
\hline $\mathrm{C} 8$ & $\begin{array}{l}25 \% \text { CLFB } \\
\text { (Gluten+SSL+FAA+AA+Pentosanase) }\end{array}$ \\
\hline C9 & $\begin{array}{l}25 \% \text { CLFB } \\
\text { (Gluten+SSL+FAA+AA+Xylanase) }\end{array}$ \\
\hline
\end{tabular}

${ }^{1} \mathrm{CB}$ : Commercial bread. ${ }^{2} \mathrm{TFB}$ : Traditional flat bread. ${ }^{3} \mathrm{CLFB}$ : Cereal-legume flour blend. ${ }^{4}$ SSL: Sodium stearoyl-2-lactylate. ${ }^{5}$ FAA: Fungal alpha amylase. ${ }^{6} \mathrm{AA}$ : Ascorbic acid. ${ }^{7}$ TG: Transglutaminase. ${ }^{8} \mathrm{GO}$ : Glucose oxidase

TFB was prepared according to the method given by Akbaş (2000). For the preparation of C1 TFB; $100 \mathrm{~g}$ wheat flour, $2.5 \mathrm{~g}$ baker's yeast, $1.5 \mathrm{~g}$ salt, $1 \mathrm{~g}$ sugar and water were kneaded until obtaining a homogeneous dough. After the dough was allowed to ferment at $30^{\circ} \mathrm{C}$ for $60 \mathrm{~min}$, dough rounded into a ball shape and allowed to rest for $6 \mathrm{~min}$ at room conditions. The dough was flattened to the final thickness of $10 \mathrm{~mm}$ by a stainless steel circle of $17 \mathrm{~cm}$ diameter and then baked for $5 \mathrm{~min}$ on sac (metal plate heated by electrical resistances, $1500 \mathrm{~W}$ ). To produce C2 TFB; wheat flour was replaced with $25 \%$ of CLFB. The enzyme combinations given in Table 1 were used from $\mathrm{C} 3$ to $\mathrm{C} 9$ TFB. The same method that was used in C1 TFB was also applied for the production of C2-C9 TFB.

\subsection{Bread analyses}

All bread samples were cooled at the room temperature $\left(25 \pm 2^{\circ} \mathrm{C}\right)$ for $60 \mathrm{~min}$, then the weight and volume of $\mathrm{CB}$ was measured (Elgün et al., 2001). The specific volume of $\mathrm{CB}$ was calculated by dividing the volume value by the weight. Diameter and thickness values of TFB samples were measured. The spread 
ratio was obtained by dividing the diameter values to the thickness values. Colour values $\left(L^{*}, a^{*}\right.$ and $\left.b^{*}\right)$ of breads were obtained by the colourimeter Minolta CR 400 (Konica Minolta Inc., Osaka, Japan). Saturation index $(S I)$ was calculated by $\left(a^{* 2}+b^{* 2}\right)^{1 / 2}$ formula and hue angle (if $a^{*>0}$ and $b^{*>0}$, $\arctan \left[b^{*} / a^{*}\right.$; if $a^{*<0}$ and $b^{*}>0$, arctan $\left.\left[b^{*} / a^{*}\right]+180^{\circ}\right)$ was calculated using $a^{*}$ and $b^{*}$ values (Francis, 1998). Hardness values of both breads were measured using an aluminum $36 \mathrm{~mm}$ diameter cylindrical probe $(\mathrm{P} 36 / \mathrm{R})$ via a texture analyzer (Stable Micro Systems TA-XT.Plus, Surrey, UK) according to AACC 74-09 method at the end of $24 \mathrm{~h}$ and $72 \mathrm{~h}$ (Anon., 2002).

Sensory evaluation of the bread samples was performed by 25 panellists from the Food Engineering Department of Necmettin Erbakan University. Sensory properties (symmetry, pore structure, taste, odour, appearance and overall acceptability) of breads were evaluated using the hedonic scale 1-7 (1= dislike very much, 7 = like very much).

JMP (SAS Institute Inc., NC, USA) software was used to perform the statistical analyses. The averages of the data obtained were compared with each other and listed in the tables. All analyses were the average of triplicate measurements on the duplicate samples.

\section{Results and Discussion}

Physical properties of CB are presented in Table 2. Volume and specific volume of $\mathrm{C} 2 \mathrm{CB}$ reduced in

Table 2

Physical properties of CB samples. ${ }^{1}$

\begin{tabular}{lccccc}
\hline Formulations & $\begin{array}{c}\text { Weight } \\
(\mathrm{g})\end{array}$ & $\begin{array}{c}\text { Volume } \\
(\mathrm{ml})\end{array}$ & $\begin{array}{c}\text { Specific volume } \\
(\mathrm{ml} / \mathrm{g})\end{array}$ & $\begin{array}{c}\text { Hardness } \\
24 \mathrm{~h} \\
(\mathrm{~F}, \mathrm{~g})\end{array}$ & $\begin{array}{c}\text { Hardness } \\
72 \mathrm{~h} \\
(\mathrm{~F}, \mathrm{~g})\end{array}$ \\
\hline $\mathrm{C} 1$ & $139 \pm 0.85^{\mathrm{c}}$ & $372 \pm 2.83^{\mathrm{a}}$ & $2.67 \pm 0.03^{\mathrm{a}}$ & $2726 \pm 8.7^{\mathrm{e}}$ & $3555 \pm 9.3^{\mathrm{f}}$ \\
$\mathrm{C} 2$ & $143 \pm 0.85^{\mathrm{a}}$ & $255 \pm 1.41^{\mathrm{f}}$ & $1.78 \pm 0.05^{\mathrm{d}}$ & $5321 \pm 8.3^{\mathrm{a}}$ & $5975 \pm 10.5^{\mathrm{a}}$ \\
C3 & $142 \pm 0.42^{\mathrm{abc}}$ & $322 \pm 1.41^{\mathrm{e}}$ & $2.28 \pm 0.04^{\mathrm{c}}$ & $3181 \pm 8.7^{\mathrm{c}}$ & $4499 \pm 8.1^{\mathrm{b}}$ \\
$\mathrm{C} 4$ & $141 \pm 0.57^{\mathrm{abc}}$ & $337 \pm 0.71^{\mathrm{c}}$ & $2.39 \pm 0.04^{\mathrm{bc}}$ & $3103 \pm 4.9^{\mathrm{d}}$ & $4335 \pm 9.2^{\mathrm{c}}$ \\
C5 & $141 \pm 0.71^{\mathrm{abc}}$ & $325 \pm 1.41^{\mathrm{de}}$ & $2.30 \pm 0.06^{\mathrm{c}}$ & $3250 \pm 11.1^{\mathrm{b}}$ & $4521 \pm 10.9^{\mathrm{b}}$ \\
C6 & $142 \pm 0.57^{\mathrm{abc}}$ & $327 \pm 2.83^{\mathrm{de}}$ & $2.31 \pm 0.06^{\mathrm{c}}$ & $3062 \pm 9.9^{\mathrm{d}}$ & $3871 \pm 16.2^{\mathrm{d}}$ \\
C7 & $142 \pm 0.57^{\mathrm{ab}}$ & $330 \pm 0.71^{\mathrm{cd}}$ & $2.33 \pm 0.03^{\mathrm{c}}$ & $2695 \pm 15.3^{\mathrm{e}}$ & $3752 \pm 9.6^{\mathrm{e}}$ \\
C8 & $141 \pm 0.42^{\mathrm{bc}}$ & $355 \pm 1.41^{\mathrm{b}}$ & $2.52 \pm 0.02^{\mathrm{ab}}$ & $2090 \pm 9.8^{\mathrm{f}}$ & $3132 \pm 12.5^{\mathrm{g}}$ \\
C9 & $140 \pm 0.42^{\mathrm{bc}}$ & $362 \pm 2.83^{\mathrm{b}}$ & $2.58 \pm 0.05^{\mathrm{a}}$ & $2004 \pm 14.6^{\mathrm{g}}$ & $3059 \pm 12.5^{\mathrm{h}}$ \\
\hline
\end{tabular}

${ }^{\mathrm{I}}$ Means followed by the same letter within a column are not significantly different $(\mathrm{P}<0.05)$. Values are the average of triplicate measurements on the duplicate samples. CB: Commercial bread.

Physical properties of TFB are given in Table 3. The diameter values of TFB have varied in the range of 15.22 to $16.58 \mathrm{~cm}$. The combination of $\mathrm{C} 3$ demonstrated a very close diameter result to $\mathrm{C} 1 \mathrm{TFB}$. However, C9 combination showed the lowest diameter value. Compared to $\mathrm{C} 1 \mathrm{TFB}$, replacement of wheat flour with CLFB was significantly $(\mathrm{P}<0.05)$ reduced thickness value of $\mathrm{C} 2 \mathrm{TFB}$. On the other hand, the combinations of $\mathrm{C} 8$ and $\mathrm{C} 9$ provided the highest thickness values. The spread ratio values of TFB changed between 10.71 and 15.46. The combinations of "vital gluten, SSL, FAA and AA" (C4), "vital gluten, SSL, FAA and lipase" (C7), C8 and C9 presented lower spread ratio comparison to $\mathrm{C} 1 \mathrm{CB}$. The utilisation of $25 \%$ of CLFB in bread formulation decreased the bread volume due to the diluted gluten content as well as deterioration of the gluten network with CLFB. All the additive combinations had a positive effect on the volume and specific volume of breads compared to $\mathrm{C} 2 \mathrm{CB}$. Combination of "vital gluten, SSL and FAA" (C3) markedly improved bread volume compared to $\mathrm{C} 2 \mathrm{CB}$. SSL is considered as a dough strengthener and an emulsifier agent which provides a high volume and specific volume due to the formation of lamellar liquid films at the interfaces between starch and gluten (Gomes-Ruffi et al., 2012). FAA improves the gas holding capacity of dough during fermentation, thus it can increase the bread specific volume (Leon et al., 2002). At the same time, the combinations of "vital gluten, SSL, FAA, AA and pentosanase" (C8) and "vital gluten, SSL, FAA, AA and xylanase" (C9) provided the highest volume and specific volume results among additive combinations. Xylanase increases water absorption by dissolving water-insoluble arabinoxylan, thereby improves bread volume (Jeffries et al., 1998). The hardness values of at the end of 24 and $72 \mathrm{~h}$ have varied in the range of 2004 to $5321 \mathrm{~g}$ and 3059 to $5975 \mathrm{~g}$, respectively. C8 and C9 showed a most positive effect on the hardness of CB. Similar results were also reported by Caballero et al. (2007) who studied the effects of enzyme combination (amylase and xylanase) on dough rheology, bread quality and shelf-life. values than $\mathrm{C} 1 \mathrm{TFB}$. This result may also be related to dough strengthener effects of AA, lipase, pentosanase improvement of dough with supplemented of these enzymes in bread formulations (Gujral et al., 2003; Olesen et al., 2000; Shah et al., 2006; Steffolani et al., 2010). The combinations of additives using in CB and TFB presented similar effects on hardness values of bread at the end of $24 \mathrm{~h}$ and $72 \mathrm{~h}$. Compared to $\mathrm{C} 2$, the additives displayed significant $(\mathrm{P}<0.05)$ decrease in hardness values of TFB, at the end of 24 and $72 \mathrm{~h}$. Armero and Collar (1998) found that a combination of SSL and alpha amylase revealed lower hardness values and xylanase. In literature, there are many studies on 
in bread than control. Similar results were obtained in studies with pentosanase (Renzetti et al., 2010), GO, amylase and xylanase (Caballero et al., 2007), gluten

Table 3

Physical properties of TFB samples. ${ }^{1}$

\begin{tabular}{lccccc}
\hline Formulations & $\begin{array}{c}\text { Diameter } \\
(\mathrm{cm})\end{array}$ & $\begin{array}{c}\text { Thickness } \\
(\mathrm{cm})\end{array}$ & $\begin{array}{c}\text { Spread } \\
\text { ratio }\end{array}$ & $\begin{array}{c}\text { Hardness } \\
24 \mathrm{~h} \\
(\mathrm{~F}, \mathrm{~g})\end{array}$ & $\begin{array}{c}\text { Hardness } \\
72 \mathrm{~h} \\
(\mathrm{~F}, \mathrm{~g})\end{array}$ \\
\hline C1 & $16.56 \pm 0.04^{\mathrm{ab}}$ & $1.21 \pm 0.04^{\mathrm{c}}$ & $13.70 \pm 0.05^{\mathrm{d}}$ & $5194 \pm 13.7^{\mathrm{d}}$ & $9483 \pm 12.6^{\mathrm{e}}$ \\
C2 & $15.77 \pm 0.07^{\mathrm{e}}$ & $1.02 \pm 0.06^{\mathrm{d}}$ & $15.46 \pm 0.03^{\mathrm{a}}$ & $7223 \pm 13.4^{\mathrm{a}}$ & $14091 \pm 14.4^{\mathrm{a}}$ \\
C3 & $16.58 \pm 0.04^{\mathrm{a}}$ & $1.18 \pm 0.04^{\mathrm{cd}}$ & $14.05 \pm 0.04^{\mathrm{c}}$ & $5744 \pm 9.8^{\mathrm{b}}$ & $10342 \pm 17.2^{\mathrm{b}}$ \\
C4 & $16.39 \pm 0.04^{\mathrm{bc}}$ & $1.23 \pm 0.05^{\mathrm{bc}}$ & $13.30 \pm 0.05^{\mathrm{e}}$ & $4234 \pm 15.7^{1}$ & $8588 \pm 12.3^{\mathrm{g}}$ \\
C5 & $16.36 \pm 0.04^{\mathrm{c}}$ & $1.11 \pm 0.04^{\mathrm{cd}}$ & $14.69 \pm 0.06^{\mathrm{b}}$ & $5429 \pm 14.6^{\mathrm{c}}$ & $9897 \pm 15.7^{\mathrm{c}}$ \\
C6 & $16.07 \pm 0.04^{\mathrm{d}}$ & $1.11 \pm 0.04^{\mathrm{cd}}$ & $14.54 \pm 0.04^{\mathrm{b}}$ & $5034 \pm 13.8^{\mathrm{e}}$ & $9307 \pm 10.6^{\mathrm{f}}$ \\
C7 & $16.05 \pm 0.04^{\mathrm{d}}$ & $1.21 \pm 0.04^{\mathrm{c}}$ & $13.26 \pm 0.02^{\mathrm{e}}$ & $4920 \pm 11.5^{\mathrm{f}}$ & $9555 \pm 10.0^{\mathrm{d}}$ \\
C8 & $15.58 \pm 0.03^{\mathrm{f}}$ & $1.39 \pm 0.04^{\mathrm{ab}}$ & $11.22 \pm 0.05^{\mathrm{f}}$ & $4510 \pm 11.5^{\mathrm{g}}$ & $7850 \pm 13.2^{\mathrm{h}}$ \\
C9 & $15.22 \pm 0.03^{\mathrm{g}}$ & $1.42 \pm 0.04^{\mathrm{a}}$ & $10.71 \pm 0.06^{\mathrm{g}}$ & $4426 \pm 13.1^{\mathrm{h}}$ & $7405 \pm 10.9^{1}$ \\
\hline
\end{tabular}

${ }^{\mathrm{T}}$ Means followed by the same letter within a column are not significantly different $(\mathrm{P}<0.05)$. Values are the average of triplicate measurements on the duplicate samples. TFB: Traditional flat bread.

Colour values of CB are demonstrated in Table 4. Crust $L^{*}$ values of $\mathrm{CB}$ changed between 54.32 and 65.94. All the additive combinations in $\mathrm{CB}$ caused lower crust $L^{*}$ values than $\mathrm{C} 1$ and $\mathrm{C} 2$. Usage of $25 \%$ ratio of CLFB in $\mathrm{C} 2$ significantly $(\mathrm{P}<0.05)$ reduced crust $a^{*}$ values of $\mathrm{CB}$. The highest $a^{*}$ values were obtained using the combinations of $\mathrm{C} 3$ or "vital gluten, SSL, FAA and GO" (C6) in CB. Compared to other bread samples, the combination of $\mathrm{C} 9$ (xylanase) showed more decrease in terms of crust $b^{*}$ value in CB. It was reported that TG increased crust $L^{*}$ and $b^{*}$ values, GO and TG decreased $a^{*}$ value, and xylanase

Table 4

Colour values of CB samples. ${ }^{1}$

\begin{tabular}{|c|c|c|c|c|c|}
\hline Formulations & $L^{*}$ & $a^{*}$ & $b^{*}$ & $S I$ & Hue \\
\hline \multicolumn{6}{|l|}{ Crust } \\
\hline $\mathrm{C} 1$ & $61.98 \pm 0.04^{\mathrm{b}}$ & $9.85 \pm 0.04^{\mathrm{f}}$ & $30.54 \pm 0.06^{\mathrm{a}}$ & $32.09 \pm 0.04^{\mathrm{b}}$ & $72.12 \pm 0.10^{\mathrm{b}}$ \\
\hline $\mathrm{C} 2$ & $65.94 \pm 0.05^{\mathrm{a}}$ & $7.79 \pm 0.04^{\mathrm{g}}$ & $29.26 \pm 0.04^{\mathrm{d}}$ & $30.28 \pm 0.05^{\mathrm{e}}$ & $75.09 \pm 0.06^{\mathrm{a}}$ \\
\hline $\mathrm{C} 3$ & $57.98 \pm 0.06^{\mathrm{e}}$ & $12.87 \pm 0.02^{\mathrm{a}}$ & $29.87 \pm 0.04^{b}$ & $32.52 \pm 0.05^{\mathrm{a}}$ & $66.70 \pm 0.01^{\mathrm{ef}}$ \\
\hline $\mathrm{C} 4$ & $60.00 \pm 0.06^{c}$ & $12.10 \pm 0.03^{\mathrm{d}}$ & $29.54 \pm 0.06^{c}$ & $31.92 \pm 0.04^{\mathrm{b}}$ & $67.73 \pm 0.08^{\mathrm{d}}$ \\
\hline C5 & $59.32 \pm 0.04^{\mathrm{d}}$ & $11.30 \pm 0.04^{\mathrm{e}}$ & $28.70 \pm 0.04^{\mathrm{e}}$ & $30.85 \pm 0.05^{\mathrm{d}}$ & $68.50 \pm 0.04^{\mathrm{c}}$ \\
\hline C6 & $56.22 \pm 0.06^{\mathrm{f}}$ & $12.92 \pm 0.03^{\mathrm{a}}$ & $28.48 \pm 0.04^{\mathrm{f}}$ & $31.27 \pm 0.03^{\mathrm{c}}$ & $65.60 \pm 0.08^{g}$ \\
\hline $\mathrm{C} 7$ & $57.88 \pm 0.03^{\mathrm{e}}$ & $12.47 \pm 0.04^{\mathrm{c}}$ & $28.71 \pm 0.04^{\mathrm{e}}$ & $31.30 \pm 0.06^{\mathrm{c}}$ & $66.52 \pm 0.04^{f}$ \\
\hline $\mathrm{C} 8$ & $56.21 \pm 0.04^{f}$ & $12.20 \pm 0.04^{\mathrm{d}}$ & $28.52 \pm 0.06^{\mathrm{ef}}$ & $31.02 \pm 0.07^{\mathrm{d}}$ & $66.84 \pm 0.03^{\mathrm{e}}$ \\
\hline C9 & $54.32 \pm 0.04^{\mathrm{g}}$ & $12.65 \pm 0.03^{b}$ & $27.07 \pm 0.06^{\mathrm{g}}$ & $29.88 \pm 0.06^{\mathrm{f}}$ & $64.95 \pm 0.00^{\mathrm{h}}$ \\
\hline \multicolumn{6}{|l|}{ Crumb } \\
\hline $\mathrm{C} 1$ & $66.12 \pm 0.06^{\mathrm{g}}$ & $0.68 \pm 0.01^{\mathrm{d}}$ & $18.75 \pm 0.06^{\mathrm{f}}$ & $18.76 \pm 0.06^{\mathrm{f}}$ & $87.92 \pm 0.05^{\mathrm{a}}$ \\
\hline $\mathrm{C} 2$ & $67.13 \pm 0.05^{\mathrm{f}}$ & $2.12 \pm 0.06^{\mathrm{a}}$ & $20.89 \pm 0.05^{\mathrm{a}}$ & $20.99 \pm 0.04^{\mathrm{a}}$ & $84.20 \pm 0.17^{\mathrm{cd}}$ \\
\hline C3 & $69.26 \pm 0.04^{c}$ & $2.06 \pm 0.05^{\mathrm{ab}}$ & $19.68 \pm 0.05^{\mathrm{c}}$ & $19.79 \pm 0.04^{c}$ & $84.01 \pm 0.15^{\mathrm{d}}$ \\
\hline $\mathrm{C} 4$ & $70.01 \pm 0.02^{\mathrm{ab}}$ & $2.03 \pm 0.06^{\mathrm{ab}}$ & $19.05 \pm 0.04^{\mathrm{e}}$ & $19.16 \pm 0.05^{\mathrm{e}}$ & $83.92 \pm 0.15^{\mathrm{d}}$ \\
\hline $\mathrm{C} 5$ & $69.09 \pm 0.05^{\mathrm{cd}}$ & $2.13 \pm 0.04^{\mathrm{a}}$ & $19.66 \pm 0.04^{c}$ & $19.78 \pm 0.05^{\mathrm{c}}$ & $83.82 \pm 0.11^{\mathrm{d}}$ \\
\hline C6 & $68.48 \pm 0.06^{\mathrm{e}}$ & $1.91 \pm 0.06^{\mathrm{b}}$ & $19.96 \pm 0.06^{\mathrm{b}}$ & $20.06 \pm 0.06^{\mathrm{b}}$ & $84.54 \pm 0.19^{c}$ \\
\hline $\mathrm{C} 7$ & $69.06 \pm 0.05^{\mathrm{d}}$ & $2.07 \pm 0.04^{\mathrm{ab}}$ & $19.37 \pm 0.04^{\mathrm{d}}$ & $19.48 \pm 0.05^{\mathrm{d}}$ & $83.90 \pm 0.11^{\mathrm{d}}$ \\
\hline $\mathrm{C} 8$ & $69.91 \pm 0.06^{\mathrm{b}}$ & $1.70 \pm 0.03^{c}$ & $19.75 \pm 0.04^{\mathrm{c}}$ & $19.82 \pm 0.04^{\mathrm{c}}$ & $85.09 \pm 0.08^{b}$ \\
\hline C9 & $70.21 \pm 0.05^{\mathrm{a}}$ & $1.63 \pm 0.03^{\mathrm{c}}$ & $20.05 \pm 0.04^{\mathrm{b}}$ & $20.12 \pm 0.04^{\mathrm{b}}$ & $85.36 \pm 0.08^{b}$ \\
\hline
\end{tabular}

${ }^{1}$ Means followed by the same letter within a column are not significantly different $(\mathrm{P}<0.05)$. Values are the average of triplicate measurements on the duplicate samples. CB: Commercial bread.

Crust colour values of TFB are reported in Table 5. Crust $L^{*}$ values of TFB ranged between 55.19 to 68.72 . The combinations of "vital gluten, SSL, FAA and TG" (C5) or C7 in TFB resulted in higher crust $L^{*}$ values among all the additive combinations after $\mathrm{C} 1$ and $\mathrm{C} 2$ and TG (Gerrard et al., 1998; Salmenkallio-Marttila et al., 2004). enzyme showed a decrease on all of the colour parameters in wheat-soy breads compared to control bread (Roccia et al., 2012). Usage of C9 combination in CB resulted in the lowest SI and hue values. Usage of $25 \%$ CLFB increased crumb $L^{*}, a^{*}$ and $b^{*}$ values of CB, and so, the lowest crumb $L^{*}, a^{*}, b^{*}$ and $S I$ values were found in $\mathrm{C} 1 \mathrm{CB}$. However, $\mathrm{C} 1 \mathrm{CB}$ had the highest hue values. Among additive combinations, $\mathrm{C} 4$ and $\mathrm{C} 9$ provided higher crumb $L^{*}$ values and the combinations of C6 and C9 revealed greater result in terms of crumb $b^{*}$ and $S I$ values after $\mathrm{C} 2 \mathrm{CB}$. 
0.68 and 20.64, respectively, and the same values of bread containing xylanase were $88.26,0.75$ and 20.39 , respectively. Crust $S I$ and hue values of TFB changed between 26.31 and 30.04 and 64.14 and 81.40, respec-

Table 5

Crust colour values of TFB samples. ${ }^{1}$ tively. C2 TFB had the lowest SI value, and also the highest hue result was obtained in $\mathrm{C} 2$. Compared to $\mathrm{C} 2$, the additive combinations increased SI values while decreased hue values in TFB.

\begin{tabular}{|c|c|c|c|c|c|}
\hline Formulations & $L^{*}$ & $a^{*}$ & $b^{*}$ & $S I$ & Hue \\
\hline $\mathrm{C} 1$ & $63.47 \pm 0.04^{\mathrm{b}}$ & $10.55 \pm 0.05^{\mathrm{f}}$ & $26.87 \pm 0.04^{\mathrm{bc}}$ & $28.87 \pm 0.02^{\mathrm{d}}$ & $68.57 \pm 0.11^{\mathrm{b}}$ \\
\hline $\mathrm{C} 2$ & $68.72 \pm 0.04^{\mathrm{a}}$ & $3.93 \pm 0.04^{\mathrm{g}}$ & $26.01 \pm 0.04^{\mathrm{e}}$ & $26.31 \pm 0.05^{\mathrm{g}}$ & $81.40 \pm 0.07^{\mathrm{a}}$ \\
\hline $\mathrm{C} 3$ & $57.23 \pm 0.11^{\mathrm{e}}$ & $12.76 \pm 0.04^{\mathrm{bc}}$ & $26.74 \pm 0.07^{\mathrm{c}}$ & $29.63 \pm 0.08^{\mathrm{b}}$ & $64.49 \pm 0.01^{\mathrm{e}}$ \\
\hline $\mathrm{C} 4$ & $56.13 \pm 0.07^{\mathrm{f}}$ & $12.07 \pm 0.04^{\mathrm{d}}$ & $25.57 \pm 0.06^{\mathrm{f}}$ & $28.27 \pm 0.04^{\mathrm{e}}$ & $64.73 \pm 0.13^{\mathrm{e}}$ \\
\hline $\mathrm{C} 5$ & $59.10 \pm 0.11^{\mathrm{c}}$ & $11.19 \pm 0.04^{\mathrm{e}}$ & $25.24 \pm 0.06^{\mathrm{g}}$ & $27.61 \pm 0.03^{\mathrm{f}}$ & $66.09 \pm 0.13^{\mathrm{d}}$ \\
\hline C6 & $55.52 \pm 0.06^{\mathrm{g}}$ & $13.10 \pm 0.06^{\mathrm{a}}$ & $27.03 \pm 0.07^{\mathrm{ab}}$ & $30.04 \pm 0.09^{\mathrm{a}}$ & $64.14 \pm 0.04^{\mathrm{f}}$ \\
\hline $\mathrm{C} 7$ & $59.12 \pm 0.07^{\mathrm{c}}$ & $11.04 \pm 0.06^{\mathrm{e}}$ & $26.94 \pm 0.04^{\mathrm{abc}}$ & $29.11 \pm 0.06^{\mathrm{cd}}$ & $67.72 \pm 0.07^{\mathrm{c}}$ \\
\hline $\mathrm{C} 8$ & $57.67 \pm 0.07^{\mathrm{d}}$ & $12.59 \pm 0.04^{\mathrm{c}}$ & $26.43 \pm 0.05^{\mathrm{d}}$ & $29.28 \pm 0.07^{\mathrm{c}}$ & $64.53 \pm 0.02^{\mathrm{e}}$ \\
\hline C9 & $55.19 \pm 0.05^{\mathrm{h}}$ & $12.94 \pm 0.04^{\mathrm{ab}}$ & $27.12 \pm 0.10^{\mathrm{a}}$ & $30.05 \pm 0.11^{\mathrm{a}}$ & $64.49 \pm 0.01^{\mathrm{e}}$ \\
\hline
\end{tabular}

${ }^{1}$ Means followed by the same letter within a column are not significantly different $(\mathrm{P}<0.05)$. Values are the average of triplicate measurements on the duplicate samples. TFB: Traditional flat bread.

Sensory properties of $\mathrm{CB}$ are given in Figure 1. Generally, additive combinations positively influenced the pore structure, appearance and overall acceptability parameters in $\mathrm{CB}$ when compared to $\mathrm{C} 2$. Especially, the combinations of $\mathrm{C} 8$ with pentosanase and $\mathrm{C} 9$ with xylanase in $\mathrm{CB}$ provided a greater increase in terms of overall acceptability score in comparison to C2. Similar positive effects of xylanase on the sensory properties (symmetry, texture, flavour, taste and total score) were reported on whole wheat bread (Shah et al., 2006).

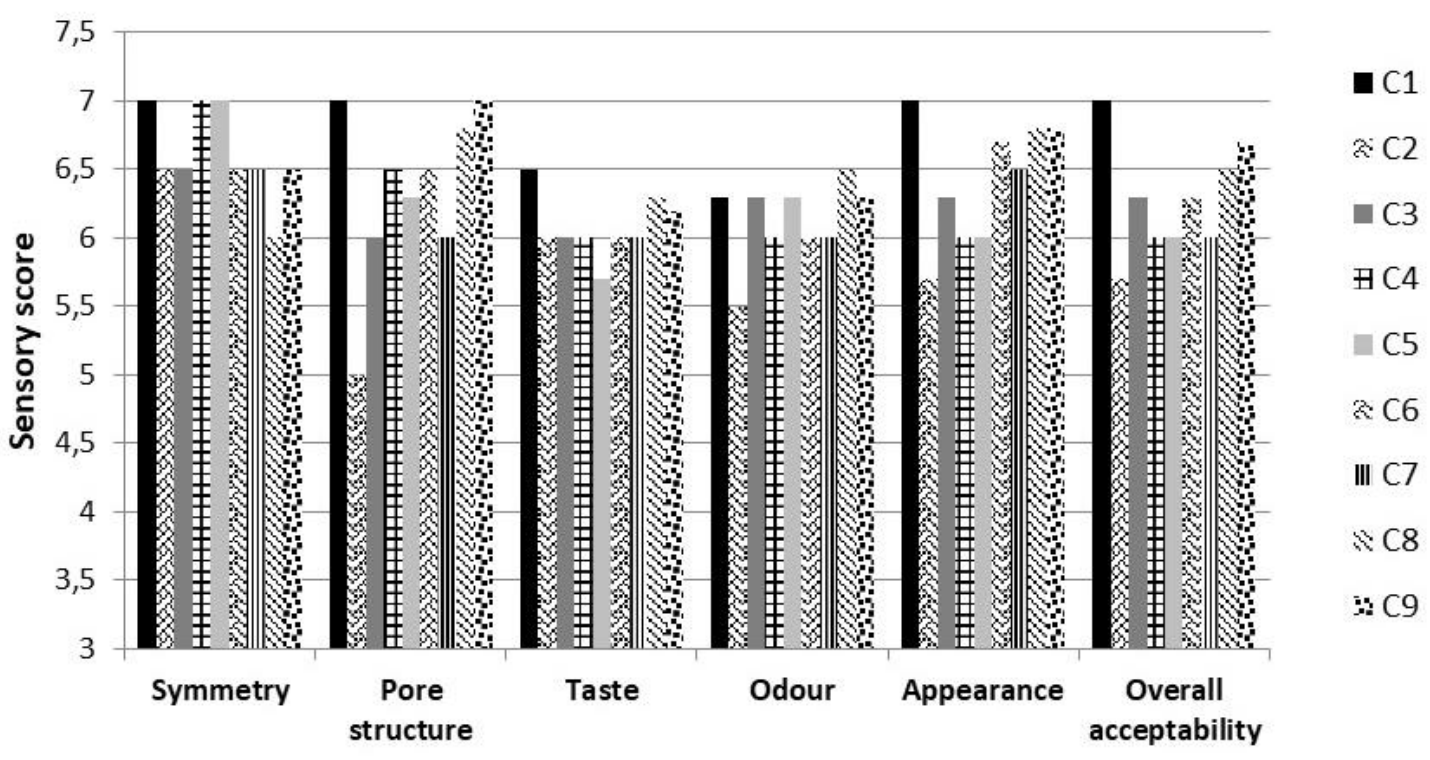

Figure 1

Sensory scores of CB samples.

Sensory properties of TFB are presented in Figure 2. The combination of $\mathrm{C} 8$ showed similar symmetry to C1 TFB. In terms of pore structure, appearance and overall acceptability, the additives displayed remarka- bly increase in TFB compared to $\mathrm{C} 2$. The highest overall acceptability scores were obtained with the combinations of $\mathrm{C} 8$ and $\mathrm{C} 9$ in TFB. 


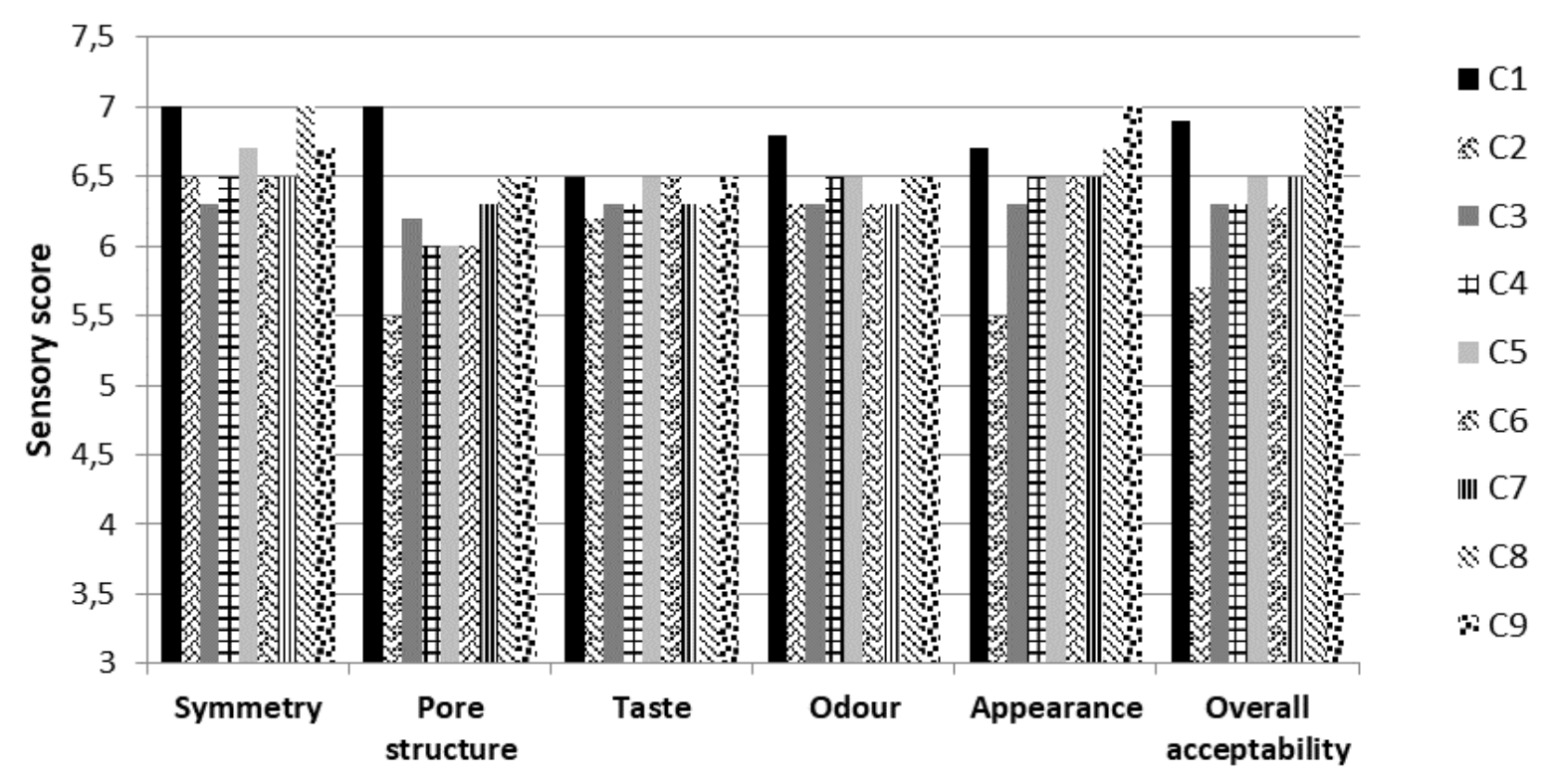

Figure 2

Sensory scores of TFB samples.

\section{Conclusions}

The utilisation of CLFB in bread formulation resulted in undesirable effects on some technological properties such as dough structure, volume and texture. Different additives were combined to overcome these effects and make the end products more acceptable by consumers. Among all the additive combinations, C8 and C9 had the greatest action on volume and specific volume parameters of $\mathrm{CB}$. In addition, the combination of $\mathrm{C} 9$ showed the lowest hardness values at the end of $24 \mathrm{~h}$ and $72 \mathrm{~h}$ in both CB and TFB. The additive combinations altered crust $L^{*}, a^{*}$ and $b^{*}$ values of $C B$ and TFB including composite flour. In terms of overall acceptability, $\mathrm{C} 9$ was the best additive combination that was followed by C8 (gluten, SSL, FAA, AA and pentosanase) $>\mathrm{C} 6$ (gluten, SSL, FAA and GO) $>\mathrm{C} 3$ (gluten, SSL and FAA) > C4 (gluten, SSL, FAA and AA), C5 (gluten, SSL, FAA and TG) and C7 (gluten, SSL, FAA and lipase) in CB. In TFB, C8 had the similar overall acceptability score to that of $\mathrm{C} 9$ which was followed by the combinations of $\mathrm{C} 5$ and $\mathrm{C} 7>\mathrm{C} 3$, $\mathrm{C} 4$ and C6. As a result, xylanase or pentosanase enzymes combined with gluten, SSL, FAA and AA could be used to improve the technological quality of bread formulations containing cereal-legume composite flour. Production of breads with superior nutritional, technological and sensory qualities could be provided using those combinations of additives.

\section{Acknowledgements}

This study was financially supported by Necmettin Erbakan University, Scientific Research Projects (BAP $-131319002)$.

\section{References}

Akbaş BE (2000). Effects of breadmaking methods on some properties and phytic acid contents of corn bread. MSc Thesis, Ankara University Food Engineering Department, Ankara, Turkey, pp. 63.

Anonymous (2002). Approved Methods of the American Association of Cereal Chemists, St. Paul: AACC.

Armero E, Collar C (1998). Crumb firming kinetics of wheat breads with anti-staling additives. Journal of Cereal Science 28: 165-174.

Belski R (2012). Fiber, protein, and lupin-enriched foods: role for improving cardiovascular health. Advances in Food and Nutrition Research 66: 147215.

Caballero PA, Gomez M, Rosell CM (2007). Improvement of dough rheology, bread quality and bread shelf-life by enzyme combination. Journal of Food Engineering 81: 42-53.

Castello P, Jollet S, Potus J, Baret JL, Nicolas J (1998). Effect of exogenous lipases on dough lipids during mixing of wheat flour. Cereal Chemistry 75: 595601.

Day L, Augustin MA, Batey IL, Wrigley CW (2006). Wheat-gluten uses and industry needs. Trends in Food Science and Technology 17: 82-90.

Elgün A, Türker S, Bilgiçli N (2001). Tahıl ve Ürünlerinde Analitik Kalite Kontrolü. Konya Ticaret Borsası Yayınları, Yayın No:2, Konya.

Francis FJ (1998). Colour analysis. In: Food Analysis, Nielsen SS (Ed.). An Aspen Publishers, Maryland, Gaithersnurg, USA, pp. 599-612.

Garcia MC, Torre M, Marina ML, Laborda F (1997). Composition and characterization of soyabean and 
related products. Critical Reviews in Food Science and Nutrition 37: 361-391.

Gerrard JA, Fayle SE, Wilson AJ, Newberry MP, Ross M, Kavale S (1998). Dough properties and crumb strength of white pan bread as affected by microbial transglutaminase. Journal of Food Science 63: 472475.

Gomes-Ruffi CR, Cunha RH, Almeida EL, Chang YK, Steel CJ (2012). Effect of the emulsifier sodium stearoyl lactylate and of the enzyme maltogenic amylase on the quality of pan bread during storage. LWT-Food Science and Technology 49: 96-101.

Gujral HS, Rosell CM (2004). Improvement of the breadmaking quality of rice flour by glucose oxidase. Food Research International 37: 75-81.

Gujral HS, Gaur S, Rosell CM (2003). Note: effect of barley flour, wet gluten and ascorbic acid on bread crumb texture. Food Science and Technology International 9: 17-25.

Hemalatha MS, Leelavathi K, Salimath PV, Prasada Rao UJS (2014). Control of chapati staling upon treatment of dough with amylases and xylanase. Food Bioscience 5: 73-84.

Jeffries TW, Yang VW, Davis MW (1998). Comparative study of xylanase kinetics using dinitrosalicylic, arsenomolybdate, and ion chromatographic assays. All rights of any Nature Whatsoever Reserved 0273-2289/98/70-72.

Leon AE, Duran E, Benedito de Barber C (2002). Utilization of enzyme mixtures to retard bread crumb firming. Journal of Agricultural Food Chemistry 50: 1416-1419.

Maeda T, Hashimito T, Minoda M, Tamagawa S, Morita N (2003). Effects of mutant thermostable $\alpha$ amylase on rheological properties of wheat dough and bread. Cereal Chemistry 80: 722-727.

Malkki Y, Virtanen E (2001). Gastrointestinal effects of oat bran and oat gum: A review. LebensmittelWissenschaft und Technologie 34: 337-347.

Olesen T, Qi Si J, Donelyan V (2000). Use of lipase in baking. U.S. Patent No: 6110508, August 29, 2000, Washington, DC: US Patent and Trademark Office.

Renzetti S, Courtin CM, Delcour JA, Arendt EK (2010). Oxidative and proteolytic enzyme preparations as promising improvers for oat bread formulations: rheological, biochemical and microstructural background. Food Chemistry 119: 1465-1473.
Roccia P, Ribotta PD, Ferrero C, Perez GT, Leon AE (2012). Enzymes action on wheat-soy dough properties and bread quality. Food and Bioprocess Technology 5: 1255-1264.

Rouau X, Surget A (1998). Evidence for the presence of a pentosanase inhibitor in wheat flours. Journal of Cereal Science 28: 63-70.

Salmenkallio-Marttila M, Roininen K, Autio K, Lahteenmaki L (2004). Effects of gluten and transglutaminase on microstructure, sensory characteristics and instrumental texture of oat bread. Journal of Agricultural and Food Science 13: 138150.

Seravalli EAG, Iguti AM, Santana IA, Filho FF (2011). Effects of application of transglutaminase in wheat proteins during the production of bread. Procedia Food Science 1: 935-942.

Shah AR, Shah RK, Madamwar D (2006). Improvement of the quality of whole wheat bread by supplementation of xylanase from Aspergillus foetidus. Bioresource Technology 97: 2047-2053.

Slavin J (2004). Whole grains and human health. Nutrition Research Reviews 17: 99-110.

Stampfli I, Nersten B (1995). Emulsifiers in bread making. Food Chemistry 52: 353-360.

Steffolani ME, Ribotta PD, Perez GT, Leon AE (2010). Effect of glucose oxidase, transglutaminase, and pentosanase on wheat proteins: relationship with dough properties and bread-making quality. Journal of Cereal Science 51: 366-373.

Su D, Ding C, Li L, Su D, Zheng X (2005) Effect of endoxylanases on dough properties and making performance of Chinese steamed bread. European of Food Research and Technology 220: 540-545.

Van Steertegem B, Pareyt B, Brijs K, Delcour JA (2013). Impact of mixing time and sodium stearoyl lactylate on gluten polymerization during baking of wheat flour dough. Food Chemistry 141: 41794185.

Zeng J, Gao H, Li G, Liang X (2011). $\alpha$-amylase and glucose oxidase as promising improvers for wheat bread. In: Fourth International Conference on Information and Computing, pp. 522-524. 